\title{
Challenges of Melon Processing Among Women Processors in Enugu-Ezike Agricultural Zone of Enugu State, Nigeria
}

\author{
Angela Ebere Obetta ${ }^{1, a}$, Ridwan Mukaila, ${ }^{1, b,}$, Ogochukwu Gabriella Onah ${ }^{1, c}$, Chukwuemeka Chiebonam Onyia ${ }^{1, d}$ \\ ${ }^{1}$ Department of Agricultural Economics, University of Nigeria, Nsukka, Nigeria \\ *Corresponding author
}

\section{A R T I C L E I N F O A B S T R A C T}

Research Article

Processing of melon plays a significant role in the livelihood of rural women as it serves as their major occupation. Despite its significant role, the women processors were faced with some challenges. This study, therefore, identified the challenges faced by women in melon processing in Enugu-Ezike Agricultural Zone of Enugu State, Nigeria. Primary data were collected from 80

Received : 26/06/2020

Accepted : 07/09/2020 respondents using a structured questionnaire coupled with an interview schedule and analysed using descriptive statistics. The results showed that the majority of the women processors were advanced in age, well experienced, do not belong to a cooperative society, and relied strictly on processing melon as their source of livelihood. They had an average income of N286,400 (USD 751.71) per annum. Low capital, poor credit facilities, high transportation cost, price fluctuation, rapid deterioration, low supply of melon, poor storage facilities, high cost of processing machine, and

Keywords:

Constraints

Marketing channels

Rural women

Livelihoods

Melon processing breakage of seed were the identified constraints facing them. The study recommended that the women processors should form a cooperative society which will help in financing and easy marketing of their products. Also, the government should provide financial assistance, good storage facilities, and subsidized melon processing machine to increase efficiency.

angela.obetta@unn.edu.ng (i) http://orcid.org/0000-0002-0562-2648 (iD) http://orcid.org/0000-0002-9883-2109

b@ridwan.mukaila@unn.edu.ng chukwuemeka.onyia@unn.edu.ng

\section{Introduction}

Egusi melon Colocynthis citrillus lanatus locally called egusi in Nigeria belongs to the family Cucurbitaceae which consist of watermelon, pumpkin, and cucumber (Olaniyi and Tella, 2011; Oluba et al., 2011; Iwuchukwu and Ekeh, 2017). Egusi melon is a native of Africa, which has probably been introduced to Asia, Iran and Ukraine (Schippers, 2000). It is an economically important crop globally, it is produced on a large scale in Nigeria with the yield ranging from 131 to $1005 \mathrm{~kg} / \mathrm{ha}$ (Amali et al., 2013; Oyediran et al., 2016). Its existence in Nigeria dates back to the 17th century (Oloko and Agbetoye 2006; Abiola and Ekunrin, 2016).

Women contribute significantly to the production, processing and marketing of egusi melon in Africa, especially in Nigeria, and other developing nations. Egusi melon plays a major role in the farming system of West Africa, it serves as cover crops, fertilizing the soil, and suppressing weeds (Abiola and Daniel, 2014). It also plays a vital role in the economic status of the rural farmers especially the women. Egusi is a popular seed widely used to make varieties of soups in Nigeria where it results in flavoring, fat binding, emulsifying, and thickening (Eze et al., 2017). It is a good source of minerals such as magnesium, lead chloride, calcium, manganese, sulphur, phosphorus, potassium, iron and zinc; vitamins such as vitamins B1 and B2; amino acids such as methionine, tryptophan, niacin, and arginine (Brande et al., 2012). It also has some medicinal benefits such as anti-diabetic, anti-microbial, anti-ulcer, anti-platelet, free radical scavenging and anti-oxidant (Milind and Kulwant, 2011). The seed of melon contains $50 \%$ oil, $6.4 \%$ moisture, $37.4 \%$ protein, 3.6\% ash and 2.6\% fibre. (Ajibola et al., 1990; Brande et al., 2012).

Processing of melon involves the removal of pod, fermentation, coring, washing, drying, shelling, and cleaning (Kushwaha et al., 2005). The dried seed is further processed either manually or mechanically to remove the shell from the seed. This operation can be done in the field or at the storage house (Nwakire et al., 2011). The traditional method of shelling melon is time-consuming, 
tedious, inefficient, slow, and has a low output, thus affecting the availability of melon in the market. The mechanical method is needed to sustain melon production and conserve some energy used by women in processing melon (Ukonze et al., 2016). The mechanical method is fast and can produce a large quantity of melon seed (cotyledon) from the husk for the market (Shittu and Ndrika, 2012). The use of melon shelling machines to shell melon is a relieve to farmers and melon processors as compared to the manual or traditional method which bruise and injure human fingers (Nkakini et al., 2007). Processing of melon serves as a means of livelihood for rural dwellers, especially among the women. Processing of melon has the potential of alleviating poverty which is very high in the rural areas by providing the processors with the cash needed to meet up with the basic needs.

As important as this crop with great potentials and serves as a means of livelihood to many households in the study area, the women processors are still faced with some challenges. The need to identify the constraints they faced in processing melon became necessary. Because of this background, this study aims at describing the socioeconomic characteristics of the women processors, identify the marketing channel and the constraints faced by women melon processor in Enugu-Ezike Agricultural Zone of Enugu State, Nigeria.

\section{Materials and Methods}

\section{Study Area}

The study was carried out in Enugu-Ezike Agricultural zone in Enugu State. It was purposively selected because the major livelihood of the people in the zone is farming and there are a lot of egusi melon women processors in this zone. Enugu-Ezike shares boundaries with Kogi State on the west, Nsukka LGA on the south, Benue State on the North and Isiuzo LGA on the East (ENADEP, 2015). It has a population of 585,225 and a landmass of approximately $700 \mathrm{~km}^{2}$.

\section{Sampling Procedure}

A three-stage sampling technique was used to select the respondents for the study. The first stage involved a purposive selection of two local government areas (LGAs) (Igbo-Eze South and Udenu) out of the three local governments that made up Enugu-Ezike Agricultural Zone. Igbo-Eze South and Udenu LGAs were selected for this study due to the predominance of women melon processors in the areas. The second stage involved a random selection of two markets from each of the two LGAs, giving a total of four markets. The third stage involved a random selection of twenty women melon processors from each market, making a total of 80 respondents for the study.

\section{Data Collection Method}

The study adopted a cross-sectional survey design. The source of data used for this study was generated primarily. This involved the use of a structured questionnaire designed to capture the vital socioeconomic data needed, marketing channels and the constraints faced by the women processor of egusi melon. An interview schedule was also granted where necessary. The response of these women processors forms the primary data used.

\section{Data Analysis}

Data collected were analysed using descriptive statistical analysis and Likert-type scale. The descriptive statistical analyses used include frequency distribution tables, means and percentage. These were used to describe the socio-economic profiles of the respondents and to identify the marketing channel of the women melon processors.

In analysing the level of constraints in the marketing of melon among women processor in Enugu-Ezike Agricultural zone, a 4-point Likert scale rating was used. A set of problems were itemized and respondents were asked to indicate their perceived level of severity of each of the problems. The respondents were also allowed to mention additional problems and rate them according to their severity. The scale ranges from extremely serious (4), very serious (3), moderately serious (2) and not serious (1). The mean score was computed for each respondent based on the four-point scale.

$$
\bar{X}=\frac{\sum X}{N}=(4+3+2+1) / 4=10 / 4=2.5
$$

The mean score of 2.5 was used as the cut-off point. Any constraints of the women processors with a score of less than 2.5 does not seriously affect women processors, but any constraints with the score greater than 2.5 seriously affect the women processors. To further categorise the level of severity of each problem into extreme serious, very serious, moderately serious and not serious, the study used an interval scale of 0.5 . Therefore, any mean score below 2.5 was considered not serious. Any mean score between 2.5 and 2.99 was considered moderately serious, while any mean score between 3.0 and 3.49 was considered as very serious. Also, any mean score of 3.5 or above was considered an extremely serious problem affecting the egusi melon women processors. A weighted score was also used to rank the problems based on their seriousness.

\section{Results and Discussion}

Socio-Economic and Institutional Characteristics of the Respondents

Table 1 shows the summary statistics of the socioeconomic and institutional profile of the respondents. The household characteristics examined include age, educational status, marital status, processing experience, major occupation, household size, annual income, cooperative membership, and source of fund.

The majority of the women processors $(57.4 \%)$ were between the ages range of 41 to 50 years. This suggests that the majority of the processors were of middle age, they were still in their economic active age that can make a positive contribution to melon processing. Those with 30 years and below ware 5 percent. 31-40 years, 51-60 and above 60 are 18.8 percent, 13.8 percent and 5 percent respectively. They had an average age of 51 years. The majority $(86.3 \%)$ ware married while 11.3 and 2.5 percent are single and widowed, respectively. Regarding the educational status, the majority of the processors $(52.5$ percent) had the first school leaving certificate, $22.5 \%$ of them had a secondary school education, $15 \%$ had tertiary education while only 10 percent did not have any formal 
education. Because the level of education is low in most rural areas of sub-Saharan Africa, Nigeria inclusive, where many women have only primary school education and a significant proportion do not have access to education. A significant proportion of the women processors in the study area can be said to have a form of education or the other which may result in increased output/productivity. Although this level of education is low in comparison with their urban women counterpart in Nigeria and also low in comparison with rural women in developed countries. According to Klasens (2013) and Ogbonna and Obi (2007), education increases the level of production in agriculture. The majority $(58.8 \%)$ of them had between 6 and 10 persons per household. About $39 \%$ of the melon processor had 5 and below household size, while only $2.4 \%$ ware 11 above persons. Their average household size is 6 persons per household, this implies that they have relatively enough family labour which can be used in melon processing.

About 54 percent of the processors had 10 years and below experience of melon processing, $36.2 \%$ had between 10 and 20 years, $6.2 \%$ had between 21 and 30 while only $3.8 \%$ had above 30 years of experience. Their average processing experience was 7 years. This suggests that melon processing is not a new practice for the women in the study area. The majority $(77.5 \%)$ had melon processing as their major occupation, this suggests that melon processing serves as their major source of income. While $3.7 \%, 8.8 \%$, and $10 \%$ of them had trading, farming and civil servant as their major occupation, respectively.

The women processors had an average annual income of N286,400 (USD 751.71). About 39 percent of the women had between N200,001 (USD 524.94) to N300,000 (USD 787.40) per annum, 31.2\% had between N300,001 (USD 787.40) and N400,000 (USD 1049.87), 17.5\% had from N100,001 (USD 262.47) to N200,000 (USD 524.93), 10 percent had N100,000 (USD 262.47) and below while only 7.5 percent had above N400,001 (USD 1049.87) per annum. The majority $(88.8 \%)$ of them do not belong to a cooperative society while only 11.2 percent ware members of a cooperative society. This suggests low participation in cooperative society among the women melon processors. The majority $(70 \%)$ of the respondents had their source of fund from personal saving. While $21.2 \%, 2.5 \%, 2.5 \%$ and $3.8 \%$ have their source of fund from relatives and friends, moneylender, cooperative and bank respectively.

\section{Marketing Channel of Processed Melon}

Table 2 shows the marketing channel of processed melon in the study area. The majority $(78.8 \%)$ of the melon processors always sell to wholesalers, this implies that the majority of them produced in large scale and sell in a large quantities while only 21.1 percent occasionally sell to the wholesaler. About 60 percent always sell to retailers and 41.2 percent occasionally sell to retailers. About 59 percent of the women's melon processors sell to consumers occasionally, while $20 \%$ and $21.2 \%$ always and never sell to consumers respectively. These results suggest the availability of the market for their products.
Table 1. Socio-economic and institutional characteristics of the respondents $(\mathrm{n}=80)^{*}$

\begin{tabular}{|c|c|c|c|}
\hline Variables & Frequenc & Percentage & Mean \\
\hline \multicolumn{4}{|c|}{ Age (Years) } \\
\hline$\leq 30$ & 4 & 5 & \\
\hline $31-40$ & 15 & 18.8 & \\
\hline $41-50$ & 46 & 57.4 & 51.1 \\
\hline $51-60$ & 11 & 13.8 & \\
\hline$\geq 61$ & 4 & 5 & \\
\hline \multicolumn{4}{|c|}{ Marital status } \\
\hline Single & 9 & 11.3 & \\
\hline Married & 69 & 86.3 & \\
\hline Widowed & 2 & 2.5 & \\
\hline Divorced & 0 & 0 & \\
\hline
\end{tabular}

\begin{tabular}{l|ccc}
\hline No formal education & 8 & 10 \\
Primary education & 42 & 52.5 & \\
Secondary education & 18 & 22.5 & \\
Tertiary education & 12 & 15 \\
\hline \multicolumn{4}{|c}{ Household size } \\
\hline$\leq 5$ & 31 & 38.8 & \\
$6-10$ & 47 & 58.8 & 6.11 \\
$\geq 11$ & 2 & 2.4 & \\
\hline
\end{tabular}

\begin{tabular}{l|ccc}
\multicolumn{4}{c}{ Processing experience } \\
\hline$\leq 10$ & 43 & 53.8 & \\
$11-20$ & 29 & 36.2 & 7.42 \\
$21-30$ & 5 & 6.2 & \\
$\geq 31$ & 3 & 3.8 & \\
\hline
\end{tabular}

\begin{tabular}{|c|c|c|c|}
\hline \multicolumn{4}{|c|}{ Major occupation } \\
\hline Melon processing & 62 & 77.5 & \\
\hline Trading & 3 & 3.8 & \\
\hline Farming & 7 & 8.8 & \\
\hline Civil servant & 8 & 10 & \\
\hline \multicolumn{4}{|c|}{ Annual income $\mathrm{N}$ (USD) } \\
\hline$\leq 100,000(262.47)$ & 8 & 10 & \\
\hline $\begin{array}{c}100,001(262.47)- \\
200,000(524.93)\end{array}$ & 14 & 17.5 & \\
\hline $\begin{array}{c}200,001(524.94)- \\
300,000(787.40)\end{array}$ & 27 & 33.8 & $\begin{array}{l}286,400 \\
(751.71)\end{array}$ \\
\hline $\begin{array}{c}300,001(787.40)- \\
400,000(1049.87)\end{array}$ & 25 & 31.2 & \\
\hline$\geq 400,001(1049.87)$ & 6 & 7.5 & \\
\hline
\end{tabular}

\begin{tabular}{l|ccc}
\hline \multicolumn{4}{c}{ Cooperative membership } \\
\hline Member & 9 & 11.2 & 0.11 \\
Non-member & 71 & 88.8 & \\
\hline \multicolumn{4}{c}{ Source of fund } \\
Personal saving & 56 & 70 \\
Relatives and friends & 17 & 21.2 & \\
Moneylender & 2 & 2.5 & \\
Cooperative & 2 & 2.5 & \\
Bank & 3 & 3.8 \\
*Source: Field Survey, 2019.
\end{tabular}

Table 2. Marketing channel of processed melon*

\begin{tabular}{llll}
\hline Supply channel & AF $(\%)$ & OF (\%) & NF (\%) \\
\hline Wholesaler & $63(78.8)$ & $17(21.2)$ & $0(0)$ \\
Retailer & $47(58.8)$ & $33(41.2)$ & $0(0)$ \\
Consumer & $16(20.0)$ & $47(58.8)$ & $17(21.2)$ \\
\hline
\end{tabular}

AF: Always Frequency, OF: Occasionally Frequency, NF: Never Frequency, *Source: Field Survey, 2019. 


\section{Challenges Faced by Melon Women Processors}

Table 3 presents the results of the Likert scale used in identifying the constraints faced in melon processing in the study area. The identified severe constraints affecting the women melon processors were low capital, poor credit facilities, high transportation cost, price fluctuation, rapid deterioration, low supply of melon, poor storage facility, high cost of machine, and breakage. While only the high cost of labour was not found to be a serious problem for the women melon processors among the perceived problems by the women melon processors in the study area. Low capital was ranked first among the problems faced in melon processing. Capital is a major factor of production which other factors depend on. Poor financing will affect the activities of the women engaged in melon processing. Manual processing of melon is a tedious process, most of the women processors were unable to purchase the mechanical processing machine as a result of low capital and poor credit facilities. Adequate credit facilities are an engine for the effective management of an enterprise especially the agricultural enterprise. Lack of agricultural credit is the major factor responsible for the reduction in the contribution of agriculture to Nigeria economy (Philip et al., 2009). The women processors were also faced with high transportation costs which adds more to their cost of production. Price fluctuation was found to be a severe problem affecting the women processor. Rapid deterioration as a result of poor storage facilities also hinders their activities. The processors were unable to store their product during the season for offseason purposes as a result of a lack of storage facilities. Some processor complaints of a low supply of melon during offseason. This is because most farming activities are rain-fed and the majority of the farmers were unable to produce melon during the dry season. The high cost of the machine is another challenge faced by the women processors. According to Ukonze et al., (2016), processing machines are very expensive to buy, operate, and maintain. Breakage of melon seed during processing was also reported as a challenge. Further analysis revealed that low capital, lack of credit facilities, high transportation cost, price fluctuation, rapid deterioration, low supply of melon and poor storage facilities were very serious challenges faced by the melon women processor. The high cost of machine and breakage of seed was found to be a serious challenge.

Table 3. Challenges faced by melon women processors*

\begin{tabular}{|c|c|c|c|c|c|c|c|c|}
\hline Constraints & $\begin{array}{c}\text { ES } \\
\text { Freq }(\%)\end{array}$ & $\begin{array}{c}\text { VS } \\
\text { Freq }(\%)\end{array}$ & $\begin{array}{c}\mathrm{S} \\
\text { Freq }(\%)\end{array}$ & $\begin{array}{c}\text { NS } \\
\text { Freq }(\%)\end{array}$ & WS & M & $\mathrm{R}$ & Rank \\
\hline Low capital & $56(70)$ & $9(11.3)$ & $9(11.3)$ & $6(7.4)$ & 275 & 3.44 & VS & $1 \mathrm{st}$ \\
\hline Lack of credit facilities & $38(47.5)$ & $30(37.5)$ & $6(7.5)$ & $6(7.5)$ & 260 & 3.25 & VS & 2nd \\
\hline High transportation cost & $42(52.5)$ & $17(21.2)$ & $18(22.5)$ & $3(3.8)$ & 258 & 3.23 & VS & 3rd \\
\hline Price fluctuation & $34(42.5)$ & $28(35)$ & $18(22.5)$ & $0(0)$ & 256 & 3.20 & VS & 4 th \\
\hline Rapid deterioration & $33(41.3)$ & $29(36.3)$ & $9(11.2)$ & $9(11.2)$ & 246 & 3.08 & VS & 5 th \\
\hline Low supply of melon & $30(37.4)$ & $32(40)$ & $9(11.3)$ & $9(11.3)$ & 243 & 3.04 & VS & 6 th \\
\hline Poor storage facility & $30(37.4)$ & $32(40)$ & $9(11.3)$ & $9(11.3)$ & 243 & 3.04 & VS & 6 th \\
\hline High cost of machine & $34(42.5)$ & $13(16.2)$ & $30(37.5)$ & $3(3.8)$ & 238 & 2.98 & $\mathrm{~S}$ & 8th \\
\hline Breakage of seed & $12(15)$ & $33(41.3)$ & $21(26.3)$ & $14(17.4)$ & 203 & 2.54 & S & 9th \\
\hline high cost of labour & $2(2.5)$ & $1(1.2)$ & $20(25)$ & $57(71.3)$ & 108 & 1.35 & NS & $10^{\text {th }}$ \\
\hline
\end{tabular}

$\mathrm{ES}=$ extremely serious, VS = very serious, $\mathrm{S}=$ serious NS = not serious, WS = weighted score, $\mathrm{M}=$ mean, R = remarks, *Source: Field Survey, 2019.

\section{Conclusion}

Melon processing was dominated by married women who are still in their active age and have a larger household size. Only a few of them belong to a cooperative society. It can be inferred that there is an available market for the processed egusi melon in the study area. The serious challenges facing the women's melon processors based on their level of severity are low capital, poor credit facilities, high transportation cost, price fluctuation, rapid deterioration, low supply of melon, poor storage facility, high cost of machine, and breakage of seed. We recommend the formation of a cooperative society among women melon processors which will help them in their financial obligations and easy marketing of their products. The government and non-governmental organizations should provide financial assistance, good storage facilities, and subsidized melon processing machine to increase their efficiency.

\section{References}

Abiola MO, Daniel I. 2014. Efficiency of melon production in Oredo and Egor Local Government Area of Edo State, Nigeria. International Journal of Agriculture Innovations and Research, 2(5): 732-738.
Abiola C, Ekunrin MF. 2016. Effect of fermentation on the microbial, nutrient and anti-nutrient contents of melon (Cucumis melo L) Husk. Microbiology Journal, 6(12): 9-14. DOI: $10.3923 / \mathrm{mj} .2016 .9 .14$.

Ajibola OO, Eniyemo SE, Fasina OO, Adeko KO. 1990. Mechanical extraction of oil from melon seeds. Journal of Agricultural Engineering Research, 45(1): 45-53. DOI: 10.1016/S0021-8634(05)80137-4.

Amali PE, Kortse A, Terkimbi P. 2013. The quality of egusi melon (Citrullus lanatus thumb matsum and Naki) seed derived from fruits harvested at different growth stages and different positions on the mother plant. International Journal of Scientific and Research Publication, 3(4): 1-7.

Brande YM, Adam NM, Jamare BO, Azmi Y. 2012. Physical and mechanical properties of "Egusi Melon Fruit. International Journal of Agricultural Research, 7:494-499. DOI: 10.3923/ijar.2012.494.499.

ENADEP. 2015. Enugu State Agricultural Programme; Annual Report, pp 27. Published by Enugu State Government of Nigeria.

Eze EI, Adamade CA, Anyaeji FO, Mohammed BT, Ozumba IC. 2017. Socio-economic characteristics of processor use of Melon Sheller in Edu Local Government Area, Kwara State, Nigeria. International Journal of Agricultural and Environmental Sciences, 2(1), 11-14. 
Iwuchukwu1 JC, Ekeh GO. 2017. Characterization and challenges of melon farmers in Enugu Ezike Agricultural Zone of Enugu State, Nigeria. Asian Journal of Agricultural Extension, Economics\& Sociology, 15(1): 1-9. DOI: 10.9734/AJAEES/2017/29309.

Reimers M, Klasens S. 2013. Revisiting the role of education for agricultural productivity. American Journal of Agricultural Economics, Agricultural and Applied Economics Association, 95(1): 131-152. DOI: 10.1093/ajae/aas118.

Kushwaha HL, Srivastava AP, Singh H. 2005. Development and performance evaluation of an Okra Seed Extractor. Agricultural Engineering International: CIGR Journal. 7(52): $1-10$.

Milind P, Kulwant S. 2011. Musk melon is eat-must melon. International Research Journal of Pharmacy, 2(8): 52-57.

Nkakini SO, Ayotamuno MJ, Maeba GPD, Ogaji SOT, Probert SD. 2007. Manually powered continuous flow maize sheller. Applied Energy, 84: 1175-86. DOI: 10.1016/ j.apenergy.2007.05.009.

Nwakire JN, Ugwuishiwu BO, Ohagwu CJ. 2011. Design, construction and performance analysis of a maize thresher for rural dweller. Nigerian Journal of Technology, 30: 49-51.

Ogbonna PE, Obi IU. 2007. Effect of time to planting and poultry manure application on growth and yield of Egusi melon (Colocynthis Citrullus L.) in a derived savannah AgroEcology. Agro-Science Journal of Agriculture, Food, Environmental and Extension, 6(2): 33-38. DOI: 10.4314/ as.v6i2.1568.

Olaniyi JO, Tella BA. 2011. Effect of nitrogen and potassium fertilizers on the growth, seed yield and nutritional values of egusi melon (Citrullus lanatus (thumb) manf.) in Ogbomoso South-West Nigeria. International Research Journal of Plant Science, 2(11): 328-331.
Oloko SA, Agbetoye LAS. 2006. Development and performance evaluation of a melon depodding machine. Agricultural Engineering International: CIGR Journal, 8: 1-10.

Oluba OM, Adeyemi O, Ojieh GC, Isiosio OI. 2011. Fatty acid composition of Citrullus lanatus (Egusi Melon) oil and its effect on serum lipids and some enzymes. The Internet Journal of Cardiovascular Research, 5:2.

Oyediran WO, Omoare AM, Ajagbe BO. 2016. Factors affecting sustainability of melon (Egusi) production in rural farming households of Southwest, Nigeria. American Journal of Agricultural Research, 1(1): 0001-0012.

Philip D, Nkonya E, Pender J, Oni OA. 2009. Constraints to increasing agricultural productivity in Nigeria: A Review. NSSP Working Paper 6. Abuja, Nigeria: International Food Policy Research Institute (IFPRI). Available from: https://ebrary.ifpri.org/cdm/ref/collection/p15738coll2/id/18 535. [Accessed: 01.08.2020].

Schippers RR. 2000. Africa Indigenous vegetables. An overview of the cultivated species. National Resources Institute/ACPEU Technical Centre for Agriculture and Rural Co-operation. Chatham, 224p., ISBN: 0-85954-515 6. London, UK.

Shittu SK, Ndrika VIO. 2012. Development and performance tests of a melon (egusi) seed shelling machine. Agricultural Engineering International: CIGR Journal, 14(1): 157-164.

Ukonze JA, Okeke AU, Ndubuaku U. 2016. Agribusiness concerns in large scale processing and marketing of melon in Southeastern Nigeria. African Journal of Agricultural Research, 11(16): 1433-1438. DOI: $10.5897 /$ AJAR2015.10027. 